\title{
INTERVENSI NEGARA DALAM PENYEHATAN PERUSAHAAN PENGALAMAN NEGARA SEDANG BERKEMBANG
}

\author{
Suwarsono Muhammad \\ Fakultas Ekonomi Universitas Islam Indonesia
}

\begin{abstract}
This paper attempts to explain in detail the role of the state, especially in developing countries, to promote corporate recovery during the economic crisis period. In so doing, first, the paper illuminates several important reasons why the state has to intervene in the case of economic crisis. It seems that the whole process of corporate turnaround has to be initiated by the state and hence it is called state-led corporate restructuring. Second, the paper intents to explain three stages of corporate turnaround: restructuring preparation, financial sector restructuring, and corporate restructuring, followed by an explanation of corporate restructuring techniques usually used by the state. Finally, the paper shows how the state should exit from the market.
\end{abstract}

Key words: state, intervention, recovery, crisis.

\section{PENDAHULUAN}

Dengan menggunakan pandangan yang sangat sempit, sehat tidaknya perusahaan adalah urusan pemilik (pemegang saham) perusahaan. Pemilik adalah pihak yang paling berkepentingan, karena merekalah yang secara transparan menikmati atau menanggung implikasi sehat tidaknya perusahaan. Jika perusahaan sehat, pemilik akan memperoleh pembagian laba (deviden). Kekayaan mereka juga bertambah karena laba modal (capital gain) potensial yang diperoleh dari kemungkinan peningkatan harga saham di pasar. Demikian pula sebaliknya, jika perusahaan menderita sakit, merekalah yang pertama kali merasakan secara langsung akibat ketidaksehatan tersebut. Mereka tidak menerima pembagian deviden dan disaat yang sama memiliki kemungkinan menderita kerugian modal (capital loss) dari penurunan harga saham.

Kalaulah ada pihak lain yang berkepentingan terhadap sehat tidaknya perusahaan, mereka adalah manajemen, karyawan, dan kreditor. Jika perusahaan sehat, manajemen dan karyawan akan menikmati pendapatan dan benefit lain yang lebih besar. Demikian sebaliknya, jika perusahaan sakit. Sekalipun demikian, hendaknya tetap perlu diingat bahwa jika perusahaan sakit, manajemen bisa memiliki peluang menjadi pemilik dengan membeli perusahaan tersebut (management buy out). Kreditor akan memiliki tingkat keamanan yang lebih tinggi dan jaminan penerimaan pendapatan bunga terhadap dana yang dipinjamkan kepada perusahaan, jika perusahaan sehat. Hal sebaliknya yang akan didapat jika perusahaan menderita sakit.

Namun demikian hendaknya disadari bahwa tersedia kemungkinan yang cukup besar implikasi ketidaksehatan perusahaan dapat menjangkau keluar dari 
sekedar ekonomi mikro. Dampak lanjutan ketidaksehatan perusahaan dapat keluar dari sekedar di lingkungan perusahaan semata. Efek ketidaksehatan perusahaan dapat berpengaruh secara signifikan sampai pada ekonomi makro dan masyarakat secara keseluruhan. Masyarakat dapat kehilangan pekerjaan yang pada gilirannya dapat menimbulkan tingkat pengangguran yang tinggi. Jika berlanjut berkepanjangan, dapat menimbulkan kerawanan masyarakat. Ketidaksehatan perusahaan juga dapat menganggu kinerja pemerintah dalam menjaga stabilitas ekonomi makro. Ketidakmampuan perusahaan dalam melakukan ekspor, misalnya, dapat mengganggu neraca pembayaran dan ketersediaan cadangan devisa yang pada ujungnya dapat berpengaruh pada stabiltas nilai tukar mata uang. Ketidakmampuan perusahaan dalam membayar utang dapat menghancurkan industri perbankan yang pada gilirannya dapat menimbulkan kerusakan keseluruhan sistim sektor keuangan.

Semua akibat yang lebih makro tersebut dapat menjadi lebih signifikan, dalam ukuran besaran maupun waktu, jika ketidaksehatan perusahaan terjadi secara serentak: dalam jumlah yang banyak dan dalam waktu yang relatif bersamaan serta dengan tingkat kecepatan ketidaksehatan yang tinggi. Situasi inilah yang disebut dengan ketidaksehatan perusahaan secara masif dan sistemik. Dalam keadaan demikian hampir dapat dipastikan bahwa perusahaan-perusahaan yang telah sakit tersebut tidak dapat sehat kembali tanpa campur tangan negara (baca: pemerintah dan bank sentral). Pemilik dan manajemen tidak lagi memiliki kekuatan yang cukup untuk memulihkan kesehatan perusahaan, karena telah demikian buruknya lingkungan bisnis yang tersedia. Lingkungan bisnis sepertinya hampir-hampir tidak lagi menyisakan peluang bisnis. Peran dan intervensi negara menjadi tidak terelakkan. Tidak terkecuali pada negara yang mengaku mengikuti prinsip pasar bebas.

Bagian awal tulisan ini hendak menguraikan secara ringkas alasan mengapa negara harus terlibat dalam penyehatan perusahaan. Diikuti dengan penjelasan yang cukup detail tentang proses dan tahapan intervensi negara. Bagian tiga berisi tentang teknik intervensi yang dapat dilakukan oleh negara dalam membantu proses penyehatan perusahaan. Bagian berikutnya hendak menguraikan tentang bagaimana peran negara harus dikurangi ketika memang perusahaan telah sehat dan tidak lagi memerlukan intervensi. Bagian terakhir akan menguraikan secara ringkas tentang perdebatan dua paham tentang makna restrukturisasi perusahaan jika dikaitkan tidak saja dengan pertumbuhan ekonomi, akan tetapi juga kemungkinan pertumbuhan yang berkelanjutan dan berkeadilan. Hendaknya diketahui bahwa uraian peran dan intervensi negara yang dijelaskan pada bab ini lebih terkait dengan ketidaksehatan perusahaan yang masif.

\section{ALASAN INTERVENSI NEGARA}

Menurut Stone (2002: 2), peran negara diperlukan dalam penyehatan perusahaan jika terjadi ketidaksehatan secara masif dan sistemik. Artinya dalam negara tersebut telah terjadi ketidaksehatan perusahaan dalam skala besar yang 
terjadi dalam waktu relatif bersamaan dan dengan intensitas ketidaksehatan yang akseleratif. Hampir semua perusahaan yang ada di negara tersebut, khususnya perusahaan modern dan berskala ekonomi besar, tidak ada yang berada dalam kondisi sehat secara ekonomis. Hal yang demikian biasanya terjadi ketika ekonomi makro negara berada dalam krisis, yang pada mulanya didahului oleh krisis moneter. Pada tahapan yang sangat awal biasanya dimulai dan ditandai dengan penurunan kurs mata uang secara drastis yang akan dengan segera berubah menjadi krisis sektor perbankan dan keuangan. Tulisan ini tidak hendak mempersoalkan mana yang terjadi lebih dahulu antara ketidaksehatan perusahaan dan krisis ekonomi. Yang pasti adalah ketidaksehatan perusahaan terjadi disaat ekonomi negara berada dalam krisis, yang mungkin bahkan hampir ambruk (collapse).

Dengan makna yang kurang lebih sama tetapi dengan nada yang sedikit berbeda, keterlibatan negara menjadi pasti ketika negara mulai merasakan ketakutan terhadap dampak lanjutan yang mungkin ditimbulkan oleh ketidaksehatan perusahaan (Slatter, 1984: 246). Ketidaksehatan perusahaan yang berskala besar dapat memperbesar jumlah pengangguran yang merupakan salah satu persoalan yang pelik di negara sedang berkembang. Ketidaksehatan perusahaan juga dapat mengganggu sektor perbankan ketika perusahaan tidak lagi mampu membayar kembali pinjaman yang pada gilirannya dapat mengganggu ketidaksehatan perbankan. Ketidaksehatan perusahaan juga dapat memberikan ancaman pada neraca pembayaran dan sistim keuangan secara keseluruhan. Ketidaksehatan perusahaan juga dapat membuka peluang terjadinya ketergantungan pada pihak asing lebih besar yang dengan sendirinya dapat mengurangi kebanggaan nasional dan harga diri bangsa. Ringkasnya, pertimbangan keterlibatan negara tidak saja atas dasar ekonomis tetapi juga politis.

Sesuai dengan intensitas dan karakter ketidaksehatan perusahaan, peran negara, dengan demikian, dapat menjadi bersifat masif dan berskala besar, langsung maupun tidak langsung. Negara dipaksa untuk terlibat dan mengambil posisi didepan karena hanya negara yang diharapkan dapat bersikap obyektif dalam melakukan pilihan prioritas kebijaksanaan yang harus diambil ketika (lingkungan) ekonomi berada dalam krisis, terutama kebijaksanaan ekonomi dan hukum. Disaat yang sama, negara diharapkan mampu melakukan negosiasi dengan posisi tawarmenawar yang memadai ketika harus berhadapan dengan kelompok kepentingan (interest groups) yang kuat, khususnya para pemilik perusahaan. Mereka biasanya memiliki resistensi yang tinggi terhadap berbagai program penyehatan yang seharusnya dilakukan terhadap perusahaan yang dimiliki. Dengan demikian, penyehatan perusahaan yang berskala besar (large scale corporate restructuring) hanya bisa berjalan jika negara mengambil peran yang siginifikan dan menentukan. Negara sepertinya menjadi motor penggerak penyehatan perusahaan (state-led corporate restructuring).

Akibatnya, tujuan yang hendak dicapai dari keterlibatan negara tidak semata-mata hanya membantu keberhasilan proses penyehatan perusahaan. 
Penyehatan perusahaan dilihat sebagai bagian awal yang tidak terpisahkan dari tujuan untuk memulihkan kembali pertumbuhan ekonomi yang berkelanjutan ketika sektor keuangan telah juga kembali sehat. Negara akan membantu melikuidasi perusahaan yang memang tidak lagi memiliki peluang untuk kembali sehat dan membantu perusahaan yang masih memiliki peluang untuk sehat (viable) benarbenar kembali menjadi sehat dan jika mungkin berkelanjutan. Disaat yang sama, negara ingin membangun ulang sektor keuangan yang sebelumnya telah dalam posisi yang rusak parah. Semua itu diarahkan untuk mencapai pertumbuhan ekonomi yang tinggi dan berjangka panjang.

Disamping keterlibatan secara masif, kadang-kadang negara juga berperan dalam penyehatan perusahaan dengan skala yang jauh lebih kecil dan lebih bersifat insidentil (Slatter, 1984: 246-51). Negara biasanya membantu proses penyehatan perusahaan yang berada dalam sektor keuangan. Sektor keuangan adalah sektor yang peka dan jika masyarakat sudah mulai tidak lagi percaya pada sektor keuangan bisa jadi akan menimbulkan efek buruk lanjutan yang berkepanjangan. Negara juga sering membantu jika ada perusahaan besar yang sakit. Penyehatan perusahaan besar memerlukan prasyarat yang banyak dan besar yang kadangkala tidak mudah begitu saja dikelola oleh pemilik dan manajemen, misalnya soal kebutuhan dana segar yang besar. Perusahaan besar juga memiliki posisi tawar politik yang lebih besar, sehingga sering dikatakan dalam frasa terlalu besar untuk gagal (too big to fail).

Negara juga acapkali terlibat dalam penyehatan perusahaan yang menghasilkan senjata untuk pertahanan negara dan perusahaan yang dianggap memiliki nilai strategis. Pertimbangan yang sering dipakai adalah kedua jenis industri tersebut memerlukan pembiayaan yang besar dan memerlukan waktu yang relatif panjang dalam pengembangannya. Kedua jenis industri tersebut juga sering dikaitkan dengan kebanggaan nasional dan harga diri bangsa. Terakhir, negara juga bisa terlibat dalam penyehatan perusahaan yang berada dalam industri kecil, sekalipun seringkali lebih didasarkan pada pertimbangan politik dibanding ekonomi.

\section{TAHAPAN INTERVENSI}

Sekalipun keterlibatan negara dalam penyehatan perusahaan dapat bersifat masif dan berskala besar, ini tidak berarti bahwa seluruh paket intervensi dilakukan secara serentak dalam waktu yang bersamaan. Justru yang sering dan seharusnya terjadi berbagai paket intervensi tersebut dilakukan secara bertahap, melalui urutan (sequence) yang relatif ketat. Umumnya dikenal ada tiga tahapan, yakni (1) negara merumuskan kebijaksanaan ekonomi makro dan hukum yang diperlukan sebagai landasan penyehatan perusahaan; (2) negara menyehatkan sektor keuangan terlebih dahulu agar dengan ini perbankan memiliki kekuatan, keberanian, dan insentif yang cukup untuk membantu penyehatan perusahaan; dan (3) barulah intervensi negara dalam penyehatan perusahaan dimulai, setelah terlebih dahulu 
memisahkan perusahaan yang memiliki potensi dan peluang disehatkan dan yang tidak lagi memiliki kemungkinan untuk kembali sehat.

\section{PENYIAPAN LANDASAN PENYEHATAN}

Ketidaksehatan perusahaan yang masif hampir pasti terjadi bukan saja karena telah demikian banyak manajemen yang melakukan kesalahan dalam mengelola perusahaan secara serentak. Memang benar adanya bahwa manajemen memiliki sumbangan signifikan terhadap ketidaksehatan perusahaan tersebut, akan tetapi mengatakan bahwa kesalahan manajemen merupakan satu-satunya sebab adalah diagnosis yang salah yang dapat memiliki implikasi ikutan berupa terapi yang juga salah. Ketidaksehatan perusahaan yang masif hanya dapat terjadi jika disaat itu lingkungan bisnis yang tersedia jelas-jelas tidak lagi menyediakan peluang bisnis. Lingkungan bisnis, khususnya lingkungan ekonomi, hukum, dan politik, hanya menjadi sumber ancaman bisnis yang sama sekali tidak menyisakan peluang pertumbuhan perusahaan.

Dengan kata lain, ketidaksehatan perusahaan berskala besar dan sistemik hanya dapat terjadi jika lingkungan eksternal dan manajemen perusahaan secara bersama-sama tidak lagi cocok (fit) bagi pertumbuhan perusahaan. Oleh karena itu, tidak heran jika terapi yang diperlukan juga harus berkaitan dengan keduanya. Perbaikan pengelolaan perusahaan harus dilakukan dan disaat yang sama juga dilakukan perbaikan lingkungan bisnisnya. Biasanya yang disebut belakangan dilakukan terlebih dahulu dan hampir tanpa jeda diikuti dengan yang disebut pertama. Perbaikan manajemen perusahaan tidak akan memberikan hasil yang signifikan sepanjang perusahaan tidak berada dalam landasan pacu yang memungkinkan terjadinya akselerasi perbaikan. Untuk kedua hal tersebut, negara perlu melakukan intervensi secara komprehensif, tidak sekedar sepotong-potong. Bahkan ada yang mengatakan lebih baik kelebihan dari pada kekurangan dosis (Nellor, 1998: 248). Resiko kegagalan, ekonomis dan politis, bisa jadi lebh besar jika intervensi yang diberikan ternyata insidentil dan parsial.

Negara harus melihat bahwa ketidaksehatan perusahaan yang sistemik yang terjadi di saat ekonomi dalam keadaan krisis sebagai sebuah momentum untuk melakukan perbaikan semua distorsi struktural yang selama ini telah terbangun secara akumulatif. Negara harus bersedia mengakui kesalahan yang selama ini telah terjadi dan lebih penting dari pada itu adalah kesediaan membangun satu era baru (new era) yang berisi koreksi rumusan dan implementasi kebijaksanaan lingkungan bisnis (Borsuk, 1999: 138). Reformasi lingkungan bisnis, dengan demikian, disengaja dibuat untuk membangun sesuatu yang berbeda dengan karakter yang selama ini telah dimiliki sebagai landasan penyehatan perusahaan, agar perusahaan tersebut kembali memiliki keunggulan bersaing yang lebih berkelanjutan. Berbagai distorsi tersebut biasanya berkaitan dengan restorasi stabilitas ekonomi makro dan reformasi sektor keuangan termasuk didalamnya penguatan kelembagaan keuangan, 
pengetatan regulasi dan supervisi perbankan, penciptaan transparansi hubungan peran antara negara, bank, dan perusahaan. Sederhananya, tujuan yang hendak dicapai dengan reformasi lingkungan bisnis adalah menjadikan mekanisme pasar dapat bekerja lebih baik.

Untuk keperluan tersebut negara biasanya menyiapkan sejumlah paket kebijaksanaan baru yang memiliki spektrum yang cukup luas yang hampir pasti memiliki keterkaitan antar sektor. Pertama dan ini yang paling penting dibanding yang lain, negara perlu memberikan jaminan stabilitas politik dan keamanan. Tanpa ada kepastian politik yang sesungguhnya berintikan pada kejernihan visi pemerintah dalam usaha membangun kembali lingkungan bisnis, kepercayaan bisnis (business confidence) dari komunitas bisnis, nasional dan global, tidak hendak terbangun kembali. Hendaknya negara mengetahui bahwa ketidakpastian, apalagi ketidakpastian politik, merupakan musuh utama pelaku bisnis. Yang biasa terjadi justru negara merasa ragu-ragu merumuskan dan mensosialisasikan orientasi nilai-nilai politik baru yang dimiliki, karena merasa masih atau baru saja berada pada pintu pembuka keluar dari krisis.

Disamping stabilisasi politik, negara juga harus dengan segera berhasil melakukan stabilisasi ekonomi makro: moneter dan fiskal. Stabilitas moneter jauh lebih mendesak dibanding kepastian pembiayaan anggaran negara. Biasanya stabilitas moneter lebih diutamakan karena berkaitan langsung dengan pemulihan kepercayaan masyarakat bisnis, sekalipun sesungguhnya keduanya tak bisa benarbenar dipisahkan. Negara perlu dengan segera berhasil membangun stabilitas nilai tukar mata uang, harga dan inflasi, dan suku bunga. Yang disebut pertama merupakan prioritas terpenting. Stabilitas ekonomi moneter langsung berkaitan dengan tahap yang paling awal usaha penyehatan, yakni restrukturisasi utang. Lebih dari pada itu, stabilitas moneter juga dapat dilihat sebagai indikator pendahuluan yang penting tentang adanya kepastian bisnis, yang amat diperlukan oleh debitor, kreditor, dan calon investor.

Ketiga, negara juga harus dengan cepat melakukan evaluasi secara menyeluruh tentang tingkat kesehatan perusahaan secara agregat, sebagai salah satu bahan pertimbangan dalam penentuan intensitas intervensi negara. Evaluasi ini dapat dilakukan dengan melihat daya bayar utang, kebutuhan kredit baru, jumlah utang yang tak mampu dibayar, sampai pada kemungkinan besaran pembangkrutan perusahaan. Disaat yang sama, negara juga perlu menyusun strategi penyehatan secara menyeluruh untuk sektor keuangan dan perusahaan ketika sudah dapat dipastikan bahwa ketidaksehatan yang terjadi bersifat sistemik dan berskala besar. Hendaknya penyusunan strategi in melibatkan semua pihak yang berkepentingan langsung terhadap keberhasilan penyehatan, agar strategi yang disusun memiliki kredibilitas: transparan, obyektif, dan jelas metode implementasinya. Ada kecenderungan untuk menunda penyusunan strategi karena kompleksitasnya persoalan yang dihadapi. Akan tetapi hendaknya hal tersebut dihindari, karena penundaan hanya akan memperbesar iklim ketidakpastian. 
Keberhasilan penyehatan perusahaan akan sangat terbantu jika tersedia regulasi dan hukum yang mendukung dan penerapan akuntansi yang standar. Termasuk didalamnya standar penyitaan, kebijaksanaan merger dan akuisisi, konversi utang ke kepemilikan, penjualan aset, dan investasi asing. Tidak kalah pentingnya adalah regulasi tentang tata kelola perusahaan (corporate governance) yang amat diperlukan ketika proses penyehatan sedang berjalan dan nanti ketika perusahaan sudah sehat dan beroperasi secara normal. Seringkali perangkat regulasi dan hukum tersebut belum tersedia dan oleh karena itu perlu dibuat dengan segera. Kalaulah tersedia, biasanya tidak lagi tepat untuk keperluan penyehatan perusahaan, karena pengalaman penerapan hukum yang selama ini telah terjadi berjalan dengan tempo yang amat lambat. Dalam praktik, seringkali penyediaan perangkat hukum sering terlupakan atau paling tidak tertinggal dari sisi waktu, yang ternyata pada gilirannya bisa amat menghambat laju proses penyehatan. Bisa jadi memang ada kesengajaan dari pihak-pihak yang berkepentingan untuk membuat hukum yang tersedia kabur dan banyak tafsir. Dalam batas-bats tertentu, mereka mungkin lebih suka dengan sedikit ketidakpastian hukum. Syukur-syukur bisa juga terlambat dalam penyediaannya.

Terakhir, negara juga perlu mengantisipasi efek negatif yang ditimbulkan sebagai akibat samping penyehatan sektor keuangan dan perusahaan. Hampir bisa dipastikan ada biaya sosial (social costs) yang harus dibayar negara. Penutupan perusahaan besar yang berasal dari sektor riil ataupun perbankan akan menimbulkan pengangguran. Disaat yang sama, kebijaksanaan suku bunga yang tinggi biasanya juga akan membawa akibat pada kenaikan harga dan inflasi. Secara keseluruhan, bisa jadi pilihan kebijaksanaan ekonomi makro yang diterapkan membawa akibat pada peningkatan jumlah pengangguran dan penduduk miskin, khususnya diperkotaan. Sebagai bagian dari usaha mempertahankan dan memperoleh dukungan politik yang diperlukan dalam proses penyehatan perusahaan, negara mau tak mau harus membayar biaya sosial yang pasti terjadi. Biaya sosial tersebut antara lain berupa biaya transfer peningkatan pendapatan masyarakat miskin, peningkatan jumlah lapangan kerja yang tersedia sekalipun terbatas, dan biaya akses masyarakat miskin terhadap pelayanan sosial termasuk pendidikan dan kesehatan.

\section{Penyehatan Sektor Keuangan}

Ketika landasan penyehatan telah berhasil dibangun yang ditandai dengan tercapainya stabilitas ekonomi makro, apakah dengan demikian negara telah tiba waktunya mulai melakukan intervensi penyehatan perusahaan? Ternyata, jawabnya lebih cenderung pada belum saatnya. Sekalipun ada yang mempersoalkan mana yang seharusnya dikerjakan terlebih dahulu (Min, 1999: 163), akan tetapi sepertinya lebih banyak pendapat yang mengatakan bahwa intervensi penyehatan perusahaan baru dapat dilakukan setelah terlebih dahulu negara mampu membantu menyehatkan sektor keuangan, khususnya perbankan. Setelah ekonomi makro stabil 
dan diikuti dengan keberhasilan penyehatan perbankan, intervensi penyehatan perusahaan mulai mendapatkan momentum. Kalaulah hendak dipaksakan, penyehatan perbankan dan penyehatan perusahaan dilakukan secara serentak. Dengan demikian, sesungguhnya proses penyehatan perusahaan tidak saja didorong oleh negara, akan tetapi juga bersifat didorong oleh sektor perbankan (bank-led restructuring).

Pada saat ketidaksehatan perusahaan sistemik terjadi, sesungguhnya bank seakan-akan telah menjadi pemilik perusahaan (quasi-equity holders) karena demikian besarnya utang yang dimiliki perusahaan. Jika jumlah utang tersebut dibandingkan dengan jumlah modal yang dimiliki akan tampak sangat timpang. Jumlah utang jauh lebih besar dibanding jumlah modal. Fakta tersebut semakin terlihat jelas di negara sedang berkembang karena bank sering merupakan sumber pencarian dana terbesar yang tersedia. Dengan demikian, penyehatan perusahaan tidak semata-mata hanya melibatkan pemilik (lama), akan tetapi juga perbankan yang kini memiliki kepentingan terhadap pemulihan penyehatan perusahaan. Jika perusahaan sehat, bank memiliki harapan lebih besar terhadap kembalinya kredit yang telah disalurkan.

Disamping itu, proses penyehatan perusahaan hanya dapat terjadi jika perusahaan tersebut mampu menambah dana segar yang dimiliki sebagai bagian dari upaya penyehatan operasi, setelah tahapan efisiensi dilalui. Tambahan dana tersebut dapat berasal dari pemilik (lama dan baru), akan tetapi lebih sering terjadi berasal dari kredit baru yang disalurkan oleh bank. Hanya bank sehat yang berada dalam lingkungan bisnis yang juga telah sehat yang dapat memberikan tambahan kredit, ketika utang lama juga belum sepenuhnya terselesaikan secara bisnis. Ketika ketidaksehatan perusahaan sistemik terjadi, kemampuan perbankan menjalankan fungsi intermediasi juga menjadi sangat rendah. Dengan demikian tampak jelas bahwa penyehatan perbankan perlu dilakukan terlebih dahulu sebagai pengantar, kalau bukan prasyarat, penyehatan perusahaan.

Menurut Dziobek dan Pazarbasioglu (1998: 2-4), penyehatan perbankan dimaknai sebagai usaha memperbaiki kinerja yakni melalui restorasi solvabilitas dan profitabilitas dengan cara meningkatkan kemampuan kapasitas fungsi intermediasi perbankan antara penabung dan peminjam dan melakukan restorasi kepercayaan publik. Restorasi solvabilitas dilakukan dengan restrukturisasi neraca bank yakni dengan menambah modal, mengurangi utang, dan menambah nilai aset. Tambahan modal dapat berasal dari pemilik lama, pemilik baru, dan negara. Pengurangan utang dilakukan dengan cara pengalihan utang, sedangkan peningkatan nilai aset dapat dilakukan dengan cara memperbesar tingkat pengembalian utang bermasalah dan peningkatan nilai jaminan utang.

Setelah terjadi peningkatan solvabilitas, bank perlu meningkatkan profitabilitas yang diperoleh. Dengan kata lain, peningkatan solvabiltas hanyalah sebuah langkah awal (just the first step) yang biasanya jauh lebih mudah dilakukan dibanding peningkatan profitabilitas yang tidak sekedar berorientasi jangka pendek saja. Bisa 
saja setelah persoalan solvabilitas teratasi sementara, bank menjadi tidak sehat lagi karena gagal beroperasi dengan pencapaian tingkat laba tertentu. Untuk keperluan itu, bank memerlukan manajamen baru yang siap untuk melakukan banyak perubahan: strategi bersaing baru termasuk didalamanya siap melakukan pengurangan biaya operasi. Dalam prakteknya berbagai perubahan tersebut akan lebih mudah terlaksana jika didukung oleh regulasi, perundang-undangan, akuntansi yang lebih transparan yang dibantu oleh pengendalian dan pengawasan yang lebih ketat.

Untuk keperluan perbaikan solvabilitas dan peningkatan profitabilitas, negara sebelumnya harus terlebih dahulu memisahkan bank yang memiliki kemungkinan untuk dapat disehatkan (viable) dan bank yang sama sekali tidak memiliki kemungkinan untuk sehat kembali (nonviable). Kelompok bank yang termasuk kategori pertama inilah yang memiliki kesempatan mendapatkan perbaikan solvabilitas yang biasanya dilakukan dengan rekapitalisasi. Sedangkan bank yang termasuk kelompok kategori kedua harus diambil alih (taken over) oleh negara dan aset yang tersisa dijual atau dikelola oleh perusahaan pengelola aset (asset management corporation) yang sengaja dibentuk untuk keperluan itu. Bank kelompok kedua, dengan demikian, bisa menjadi bank yang tidak lagi (beku) operasi.

Namun demikian, hendaknya diketahui bahwa proses penyehatan perbankan, khususnya di Asia, bukanlah pekerjaan yang mudah dan sekali jadi. Bisnis perbankan di Asia memiliki karakteristik khas, acapkali berbeda secara diametral dengan bisnis perbankan di Amerika dan Eropa Barat. Sering dikatakan bahwa bisnis perbankan di Asia lebih dekat atau bahkan mengikuti budaya bisnis perbankan yang berlaku di Jepang (Frankel, 1998: 4-5). Hubungan antara bank, perusahaan, dan negara sering amat dekat. Oleh karena itu seringkali hubungan ketiga lembaga tersebut tidak semata-mata dibangun atas dasar pertimbangan pasar dan bisnis. Akibatnya, ketika krisis tiba, proses penyehatan (dan perubahan) perbankan yang dilakukan amat mungkin berjalan amat lambat (Cargill dkk., 1998: 186-8), karena terlalu banyak pertimbangan bukan ekonomi. Penundaan dan keterlambatan tersebut dapat berakibat pada semakin meningginya biaya penyehatan.

\section{Penyehatan Sektor Perusahaan}

Setelah stabilitas ekonomi makro dapat dicapai dan disaat yang hampir sama sektor perbankan mulai disehatkan, penyehatan sektor perusahaan baru dapat dimulai dengan sungguh-sungguh. Tidak mungkin dilakukan penyehatan perusahaan tanpa penyediaan lingkungan bisnis yang terlebih dahulu telah sehat yang membuka kemungkinan adanya kepastian dan peluang bisnis. Dalam prakteknya, perusahaan pada awalnya masih akan tetap mengandalkan sumber dana perbankan sebagai sumber dana terbesar ketika perusahaan telah mulai sehat. Perusahaan pada masa awal penyehatan juga memerlukan kesedian perbankan untuk membantu restrukturisasi utang sebelum kemudian melakukan ekspansi. Jadi, setelah kedua langkah pendahuluan tersebut diselesaikan, barulah intervensi negara dalam penyehatan sektor perusahaan dapat dimulai. 
Pada dasarnya pengertian penyehatan sektor perusahaan dengan penyehatan sektor perbankan tidak jauh berbeda. Intervensi negara dalam penyehatan sektor perusahaan bertujuan agar perusahaan-perusahaan tersebut tetap mampu bertahan hidup ketika ekonomi sedang dalam krisis. Disamping itu, juga bertujuan agar perusahaan mampu membangun kembali keunggulan bersaing yang pada akhirnya menjadikan perusahaan mampu memperoleh dan mengakumulasi laba yang diperlukan untuk pertumbuhan dan keberlanjutan hidupnya. Oleh karena itu, tahapan intervensi negara dalam penyehatan sektor perusahaan juga serupa dengan yang dijumpai pada sektor perbankan.

Pertama, negara memisahkan perusahaan yang tidak lagi bisa bertahan hidup dan tidak mungkin disehatkan kembali dengan perusahaan yang memiliki kemungkinan tidak saja dapat bertahan hidup akan tetapi juga dapat disehatkan. Kelompok pertama adalah perusahaan-perusahaan yang nilai likuidasinya lebih besar dari pada nilai jika perusahaan tersebut tetap dipertahankan hidup, setelah mempertimbangkan biaya penyehatan. Negara perlu dengan segera menyatakan bahwa kelompok perusahaan ini dinyatakan sebagai perusahaan bangkrut. Disamping atas dasar pertimbangan tingkat ktidaksehatan, negara juga tidak ingin perusahaan tersebut justru akan menambah utang yang dimiliki yang dapat dapat memperburuk tingkat kesehatan sektor perbankan yang juga sedang dalam proses penyehatan.

Namun demikian hendaknya diketahui bahwa penilaian dan penutupan perusahaan bukan pekerjaan yang sederhana dan mudah. Hampir pasti ada perlawanan politis dari pemilik perusahaan yang hendak ditutup, khususnya bagi yang memiliki hubungan politis dengan penguasa, yang di Indonesia kini dikenal dengan sebutan konglomerat hitam. Kesulitan tersebut juga dapat timbul karena adanya ketidakjelasan penilaian kinerja perusahaan selama krisis berlangsung sebagai akibat dari praktek akuntansi yang tidak dapat dipertanggungjawabkan yang selama ini digunakan. Kesulitan ini semakin nyata jika ternyata negara gagal membangun mekanisme hukum baru tentang likuidasi perusahaan. Sebelum krisis, biasanya negara sedang berkembang memiliki proses hukum likuidasi yang ruwet dan memerlukan waktu penyelesaian yang panjang. Negara juga perlu dengan segera menyiapkan mekanisme penjualan aset yang tersisa dari perusahaan yang telah dilikuidasi agar tidak terjadi penurunan nilai yang berlebihan. Kelengahan sedikit saja akan dapat membuka pintu yang sangat lebar kembalinya konglomerat hitam, bahkan mungkin dengan tingkat dominasi yang lebih besar dibanding sebalum krisis (World Bank, 2000: 85-7).

Kedua, perusahaan yang dinyatakan dapat tetap bertahan hidup dan dapat disehatkan kembali harus dibantu membersihkan neraca yang dimiliki. Negara perlu membantu perusahaan tersebut dalam melakukan restrukturisasi utang yang dimiliki dengan berbagai teknik yang mungkin, antara lain penjadwalan ulang pembayaran utang dan bunga, perubahan utang menjadi kepemilikan, dan penghapusan utang. Untuk keperluan itu negara harus membantu melakukan negosiasi dengan berbagai 
pihak yang bekepentingan terhadap restrukturisasi neraca tersebut, khususnya para kreditor: publik maupun swasta, dalam negeri maupun internasional. Sederhananya, negara harus membantu perbaikan tingkat solvabilitas perusahaan.

Terakhir, barulah kemudian, negara membantu agar perusahaan mampu menghasilkan laba yang diperlukan untuk pertumbuhan dan keberlanjutan hidup perusahaan. Negara perlu mendesak agar perusahaan melakukan efisiensi besarbesaran, baik melalui efisiensi operasi maupun perbaikan portofolio bisnis yang dimiliki. Perbaikan solvabilitas harus dapat mengantarkan perusahaan untuk beroperasi lebih efektif dan efisien sehingga mampu menghasilkan tingkat profitabiltas yang memadai. Jika tidak, perusahaan akan kembali sakit dengan tingkat ketidaksehatan yang lebih buruk dan dengan sendirinya memiliki kemungkinan penyehatan yang jauh lebih kecil. Paling tidak, penyehatan ulangan tersebut akan memerlukan biaya, ekonomis dan politis, yang jauh lebih besar. Kegagalan tersebut terbuka karena perbaikan perolehan laba jauh lebih kompleks dibanding perbaikan tingkat solvabilitas perusahaan.

Tidak kalah pentingnya, negara juga perlu mendesak perbaikan tata kelola perusahaan (corporate governance). Jangan pernah lupa, bahwa pengabaian prinsip tata kelola perusahaan yang benar inilah yang menjadi salah sebab utama terjadinya ketidaksehatan perusahaan secara masif dan sitemik. Perbaikan tata kelola ini dimaksudkan agar perusahaan dapat menerapkan prinsip pengelolaan perusahaan yang transparan dan bertanggung jawab. Perusahaan kini tidak cukup sekedar berorientasi pada perolehan laba saja yang biasanya berdimensi waktu pendek. Akan tetapi perusahaan justru didorong untuk berorientasi jangka panjang dan memperhatikan keberlanjutan hidupnya.

Perusahaan perlu memiliki kedua orientasi waktu tersebut, jangka pendek dan panjang, secara simultan. Resiko dan ekspektasi perlu dikelola dengan prinsip kehati-hatian (prudent).

Namun demikian hendaknya dicatat bahwa pengertian umum penyehatan sektor perusahaan yang baru saja diuraikan tersebut bukanlah satu-satunya pengertian. Ada pengertian lain yang mencoba mengkaitkan dengan melihat siapa yang bertanggung jawab terhadap lahirnya krisis. Jika ternyata, perusahaan besar (konglomerat) dinilai sebagai aktor utama penyebab, maka penyehatan sektor perusahaan harus diartikan juga sebagai usaha untuk mereduksi besar-besaran peran ekonomis perusahaan besar. Bahkan jika perlu negara tidak lagi memberikan kesempatan ulangan pada tumbuh berkembangnya perusahaan besar. Jika tidak, penyehatan yang terjadi hanya bersifat sementara dan krisis ulangan akan terjadi kembali dengan sendirinya. Di semua negara Asia yang mengalami krisis sejak pertengahan tahun 1997, pengertian yang kedua ini juga nyaring terdengar (Min, 1999: 135-8; Wanandi, 1999: 129; Borsuk, 1999: 139-43). Negara, sepertinya, kemudian didorong untuk bersikap anti, atau paling tidak kurang bersahabat dengan, konglomerat. 


\section{TEKNIK INTERVENSI NEGARA}

Negara memiliki cukup banyak pilihan teknik intervensi dalam proses penyehatan perusahaan. Dalam praktek, tidak ada negara yang hanya menggunakan satu jenis teknik tertentu saja, karena biasanya kurang efektif. Yang sering terjadi adalah negara menggunakan beberapa teknik yang tersedia secara bersamaan. Masingmasing teknik memiliki keunikan tersendiri, dan tak kalah pentingnya memiliki kekuatan dan kelemahan yang khas. Akibatnya, masing-masing teknik tidak selalu pas dipilih pada setiap kesempatan. Oleh karena itu, pemilihan kombinasi teknik yang digunakan tergantung pada keunikan karakteristik ketidaksehatan perusahaan yang sedang dihadapi dan lingkungan bisnis yang tersedia.

\section{MEDIASI}

Teknik mediasi menjadikan negara berperan sebagai mediator antar bank dan bank dengan perusahaan, yang dapat dilakukan baik secara informal maupun dengan cara yang lebih terstruktur (formal). Teknik ini tepat dipilih jika kreditor enggan (baca: tidak bersedia) dan atau tidak mampu melakukan penyehatan perusahaan. Ketidaksediaan dan ketidakmampuan tersebut dapat terjadi karena ketidakcukupan modal, ketidakseimbangan kekuatan negosiasi antara debitor dan kreditor, dan tidak tersedianya insentif yang cukup bagi bank dan perusahaan dalam menyelesaikan persoalan utang mereka. Contoh terbaik penerapan teknik mediasi dapat ditemui pada London Approach yang dikenal sangat adaptif sehingga mampu membangun kerjasama yang saling menguntungkan dan komprehensif antara bank dan perusahaan. Teknik tersebut dipraktekkan oleh pemerintah Inggris yang dibantu oleh Bank of England dalam menyelesaikan 160 kasus negosiasi pada tahun 198997.

Biasanya teknik mediasi tepat digunakan jika intensitas ketidaksehatan perusahaan relatif terbatas (tidak begitu masif) dan disaat yang sama lingkungan bisnis mampu memberikan dukungan yang sehat. Teknik ini sering dipilih dengan pertimbangan bahwa teknik ini membuka kemungkinan adanya jendela kemudahan penyesuaian kepentingan (adaptif) dan sekaligus adanya fleksibilitas dari berbagai pihak yang terlibat dalam negosiasi. Namun demikian, agar efektif penerapan teknik ini memerlukan syarat-syarat yang tidak mudah dipenuhi. Syarat-syarat tersebut anatara lain pemerintahan yang kredibel, stabilitas ekonomi makro, dan adanya regulasi yang mendukung. Teknik ini biasanya tidak efektif jika pemerintah harus bernegosiasi dengan banyak kreditor besar, apalagi jika berasal dari luar negeri.

\section{SKEMA INSENTIF KEUANGAN}

Sebelum menerapkan skema insentif keuangan, pemerintah harus terlebih dahulu merumuskan satu set skema insentif yang relatif telah baku. Disaat yang sama, insentif tersebut juga harus mampu memberikan rangsangan bagi kreditor dan 
debitor untuk memanfaatkannya Insentif keuangan ini biasanya berupa jaminan dan atau subsidi yang diberikan kepada debitor dan kreditor secara suka rela. Tidak ada paksaan kepada mereka untuk harus mengambil insentif keuangan yang disediakan pemerintah. Insentif tersebut antara lain dapat berupa: kompensasi bagi kreditor untuk memperpanjang waktu jatuh tempo utang dan waktu tenggang pembayaran utang (grace periods), jaminan stabilitas suku bunga dan nilai tukar mata uang, dan injeksi modal.

Teknik ini tepat diterapkan jika ketidaksehatan perusahaan terjadi secara masif dan disaat yang sama pemerintah memiliki dana yang lebih dari cukup. Pemerintah, dengan demikian, dari mula sudah menyadari adanya kemungkinan tambahan beban keuangan yang harus ditanggung dengan kemungkinan keuntungan yang segera didapat dari keberhasilan penyehatan perusahaan. Ada pertukaran keuntungan (trade off) yang pasti terjadi. Teknik ini biasanya juga dipilih jika ternyata pasar dan regulasi tidak cukup memberikan dukungan pada proses penyehatan perusahaan.

Teknik ini pernah berhasil diterapkan oleh pemerintah Meksiko pada awal 1980an dan pertengahan 1990an dan pemerintah Chili pada awal dan pertengahan 1980an. Pemerintah Meksiko membentuk dana cadangan (trust fund) yang dipakai untuk menjamin kepastian nilai tukar mata uang, yang disebut FICORCA. Akibatnya FICORCA mampu memberikan iklim yang sejuk dalam proses negosiasi utang, kepastian nilai tukar mata uang, dan memberikan suku bunga yang lebih rendah jika utang berasal dari luar negeri. Pada akhirnya, debitor, paling tidak, memiliki kelonggaran untuk bernafas (breathing space). Kurang lebih dengan insentif yang sama pemerintah Chili juga pernah menerapkannya: perpanjangan waktu jatuh tempo dan masa tenggat pembayaran utang, penetapan indeks nilai tukar mata uang, dan suku bunga pinjaman tetap.

\section{REKAPITALISASI PERBANKAN}

Rekapitalisasi perbankan tepat dilakukan jika utang yang dimiliki oleh perusahaan teramat besar yang telah mengganggu kesehatan bank dan disaat yang sama bank-bank tersebut bersedia dan bisa melakukan penyehatan terhadap diri mereka sendiri. Terganggunya kesehatan bank tersebut terjadi karena telah demikian lama perusahaan sebagai debitor tidak lagi mampu membayar utang dan bunga yang harus ditanggung. Rekapitalisasi bank amat tepat dijalankan jika bank tersebut tidak memerlukan bantuan apapun selain tambahan modal dari dana milik negara, karena tidak mungkin lagi berharap adanya tambahan modal dari pemilik atau sumber dana swasta lainnya. Secara manajerial bank tersebut boleh dikata sehat karena bank tersebut dinilai memiliki kompetensi menyehatkan dirinya sendiri.

Untun keperluan ini, negara tentu saja disyaratkan memiliki dana lebih dari cukup, karena biasanya rekapitalisasi memerlukan dana (baca: biaya) yang jauh lebih tinggi dibanding dengan rata-rata krisis perbankan. Tingginya biaya tersebut 
dapat ditemukan misalnya di Chili yakni sebesar 41 persen pendapatan nasional domestik, demikian pula di Indonesia yang mencapai lebih dari 50 persen pendapatan nasional domestiknya, sekalipun secara rata-rata umumnya biaya yang diperlukan hanya sekitar 7 sampai 14 persen (Stone, 2002: 7; Dziobek dan Pazarbasioglu, 1998), sekalipun ada juga yang menyebutnya antara 30 persen sampai 50 persen (Caprio dan Klingebiel 1996, di Cole dan Slade, 1999: 109). Negara juga diharapkan telah mempertimbangkan resiko peningkatan beban dana yang ditanggung dengan kemungkinan keuntungan yang didapat jika bank dapat dengan segera kembali sehat. Sederhananya, semua prasyarat yang berlaku pada teknik pemberian insentif keuangan berlaku juga pada rekapitalisasi bank. Namun demikian, seringkali terjadi rekapitalisasi perbankan bisa menimbulkan efek timbulnya moral yang negatif (moral hazard) bagi pemilik dan pengelola untuk tidak secara hati-hati dalam mengelola bank (Lane dan Phillips, 2002). Mereka bisa saja berspekulasi untuk memberikan kredit dengan longgar, karena kalaulah terjadi kegagalan akan mendapatkan rekapitalisasi ulang.

Untuk menghindari efek negatif yang diperkirakan muncul dan menjamin efektifitas pelaksanaan rekapitalisasi, biasanya negara membentuk badan baru yang khusus dibangun untuk keperluan itu. Di Indonesia, badan ini disebut dengan Badan Penyehatan Perbankan Nasional (BPPN). Badan ini sejak dari mula harus menyadari tentang kemungkinan tingginya biaya rekapitalisasi yang harus ditanggung jika terjadi kekurangcermatan dalam pengelolaan. Oleh karena itu, sebelum dana publik tersebut dikucurkan, harus jelas secara hukum berapa sesungguhnya sisa besar kepemilikan perusahaan yang masih menjadi milik pemegang saham. Dengan demikian jelas pula, berapa yang hendak menjadi hak kepemilikan negara. Badan tersebut juga disyaratkan membangun aturan yang baku, apakah hendak mengelola sendiri aset-aset buruk milik debitor yang (kini) dimiliki oleh bank yang mendapat kucuran modal atau akan diserahkan kepada badan lain yang khusus dibuat untuk pengelolaan aset tersebut (asset management corporation). Pengelolaan aset tersebut bukan pekerjaan yang mudah, apalagi jika dituntut untuk mendapatkan nilai pengembalian (recovery rate) yang tinggi setelah aset tersebut dijual dikemudian hari.

\section{PERUSAHAAN PENGELOLA ASET}

Perusahaan pengelola aset (asset management corporation) yang disponsori negara tepat dibentuk jika jumlah perusahaan yang sakit amat banyak dan disaat yang sama diketahui bahwa perusahaan-perusahaan tersebut juga memiliki persoalan manajemen. Berbagai kelemahan manajerial yang biasanya dihadapi antara lain adalah kekurangan modal, pengelolaan yang buruk, kurangnya pengalaman melakukan restrukturisasi utang, ketidaksediaan dan ketidaktersediaan informasi keuangan yang handal, dan ketidakseimbangan posisi negosiasi antara bank dan perusahaan. 
Perusahaan pengelola aset (PPA) tersebut dapat melakukan pembelian utang yang terkategori buruk yang dimiliki oleh perusahaan dan merubahnya menjadi kepemilikannya. Belakangan nanti, PPA dapat menjual kembali kepemilikan tersebut kepada publik, sekalipun dari mula hendaknya disadari bahwa penjualan tersebut sama sekali bukan pekerjaan yang mudah. PPA juga dapat berfungsi sebagai penyedia modal tambahan yang diperlukan oleh bank maupun perusahaan. Disamping itu, PPA juga dapat berperan sebagai perantara negosiasi antara bank dengan perusahaan dan fungsi-fungsi lain yang dapat berperan membantu percepatan penyehatan perusahaan. Jika misalnya pengadilan kebangkrutan tidak efektif, PPA dapat juga menjadi lembaga penyelesain perkara di luar pengadilan.

Sepertinya ada dua pendapat tentang kinerja PPA. PPA umumnya berhasil mengambil alih utang perusahaan, dalam jumlah antara 10 persen sampai 35 persen GDP, namun demikian penjualan aset yang telah dimiliki terkesan amat lambat dan mungkin hanya menghasilkan tingkat pengembalian yang rendah. Dalam kajiannya di sembilan negara Klingbeil (1999, di World Bank, 2000: 78) menyatakan bahwa PPA telah gagal mempercepat proses penyehatan perusahaan bahkan sering menjadi penghalang tercapainya efektifitas resolusi negosiasi.

PPA akan bekerja efektif jika pemerintah menyediakan dana yang lebih dari cukup, beroperasi secara transparan, dan memiliki sistim informasi dan manajemen yang handal. PPA juga perlu disyaratkan dari awal untuk memiliki tujuan dan target pengembalian aset yang baku. Lebih penting dari pada semua itu, PPA harus independen secara politik. Biasanya syarat yang disebut pertama dan terakhir amat sulit dipenuhi. Negara sedang tidak memiliki dana yang cukup dan disaat yang sama hubungan negara dengan perusahaan biasanya amat kental. Perusahaan sering memiliki posisi tawar menawar yang amat besar vis-à-vis negara.

\section{DIREKTUR RESTRUKTURISASI}

Negara dapat menunjuk seorang direktur restrukturisasi (restructuring director) untuk membantu mempercepat proses penyehatan. Direktur retrukturisasi (DR) ini biasanya diperlukan jika ternyata ditemukan banyak aktor bisnis (dari bank maupun perusahaan) yang memiliki kepentingan yang tidak saja berbeda, akan tetapi sering bertolak belakang satu sama lain. DR utamanya berperan untuk melakukan akselerasi proses penyehatan perusahaan. Untuk keperluan itu, DR harus mampu mendefiniskan tujuan penyehatan dengan lebih jelas, membantu mengatasi beban keuangan yang berlebihan yang ditanggung oleh debitor dan kreditor, penentuan jumlah dan prioritas bantuan keuangan yang hendak diberikan oleh pemerintah, dan pembentukan meja perundingan bagi masyarakat yang mungkin terlupakan dan tertinggal dalam penyelesaian penyehatan perusahaan.

Biasanya direktur ini diangkat sebagai anggota kabinet dan oleh karena itu ia bertanggung jawab kepada presiden. Disamping itu ia harus melaporkan kinerjanya kepada perwakilan kreditor asing, komisi restrukturisasi, perusahaan 
pengelola aset, dan badan penyehatan perbankan Dengan demikian, nampak jelas betapa besar wewenang yang dimiliki oleh $\mathrm{DR}$, bahkan terkesan proses penyehatan perusahaan dan pemulihan ekonomi menjadi sangat sentralistis. Disinilah memang terletak kekuatan dan kelemahannya sekaligus. Kuat karena semunya menjadi terkendali. Lemah karena hampir pasti membuka pintu yang lebar untuk terjadinya politisasi. Disamping itu, pasar juga cenderung kurang diberi insentif untuk terlibat. DR masih merupakan hal baru dan akibatnya masih jarang dijumpai dalam praktik. Oleh karena itu masih sulit untuk mengevaluasi kinerja yang pernah dicapai.

\section{PINTU KELUAR}

Apa yang telah dibahas tentang tahapan dan teknik intervensi negara pada dasarnya merupakan pintu masuk bagi negara untuk menjadi pemilik bank dan perusahaan yang sakit. Kepemilikan ini dapat terjadi melalui konversi utang dengan kepemilikan, rekapitalisasi bank, dan perusahaan pengelola aset. Namun demikian, kepemilikan negara tersebut tidak dapat dibiarkan berlangsung terus menerus. Kepemilikan negara bisa menjadi penghalang berjalannya operasi bank dan perusahaan secara effisien yang pada gilirannya tidak memberikan insentif yang cukup pada pasar. Disamping itu, kepemilikan negara juga dapat memberi tambahan beban fiskal, karena badan usaha milik negara cenderung memiliki kinerja yang buruk.

Oleh karena itu, negara mau tidak mau pada menjelang akhir proses penyehatan harus mengurangi bahkan menghilangkan sama sekali hak kepemilikan pada bank dan perusahaan yang ketika itu terpaksa harus terjadi. Bahkan inilah tanda terpenting dari masa akhir dan keberhasilan penyehatan. Negara harus menjual sebagian besar atau semua bank dan perusahaan swasta yang dimiliki. Bank dan perusahaan telah kembali sehat dan menjadi milik swasta kembali, yang oleh karena itu siap membantu tercapainya pertumbuhan ekonomi yang berkelanjutan. Proses privatisasi ini tidak hanya berhenti sampai pada perpindahahan hak milik dan pengendalian dari negara, akan tetapi sampai pada pergantian manajemen. Yang perlu diperhatian adalah terbukanya kemungkinan yang amat besar bahwa pemilik baru tersebut adalah lembaga keuangan asing.

Negara dapat melakukan privatisasi tersebut melalui penjualan saham yang dimiliki, melalui penawaran publik atau penjualan strategis. Teknik ini dipilih biasanya karena negara bukan pemegang saham mayoritas. Teknik ini juga lebih disukai oleh negara karena membuka peluang terjadinya penyebaran pemilikan saham yang bisa mengakibatkan terjaganya pengelolaan perusahaan secara independen. Jika pemerintah sepenuhnya menjadi satu-satunya pemilik, biasanya penjualan dilakukan dengan teknik menjual perusahaan. Apalagi jika perusahaan tersebut telah sepenuhnya dinyatakan sehat. Negara juga perlu melakukan likuidasi terhadap bank dan perusahaan yang gagal disehatkan. 
Keseluruhan proses penyehatan sejak dari stabiliasasi ekonomi makro sampai pada selesainya privatisasi dapat berjalan dalam waktu yang relatif lama, minimal lima tahun. Di Chili berlangsung sejak akhir 1981 yang ditandai dengan pengambilalihan bank sakit dan sampai tahun 1989 proses privatisasi belum berakhir. Demikian pula pengalaman negara lain seperti Polandia, Hongaria, Filipina, dan Indonesia. Malaysia dan Korea Selatan mungkin termasuk pengecualian karena memerlukan waku yang lebih pendek dibanding waktu rata-rata tersebut. Pendeknya waktu tersebut bisa terjadi karena dari mula proses penyehatan didesain secara tepat dan transparans. Perumusan tujuan jelas dari proses penyehatan dan dukungan publik amat diperlukan untuk menangkal perlawanan politik dari berbagai pihak yang mungkin merasa dirugikan. Yang tak kalah penting dan sekaligus paling sering ditinggalkan adalah dukungan regulasi dan hukum yang amat diperlukan dalam konsistensi implementasi.

\section{DAFTAR PUSTAKA}

Borsuk, Richard. (1999). Reforming Business in Indonesia dalam Post-Soeharto Indonesia, Renewal or Chaos diedit oleh Geoff Forrester. Singapura: Institute of Southeast Asian Studies.

Cole, David C. dan Slade, Betty F. (1996). Building a Modern Financial System: the Indonesian Experience. Cambridge: Cambridge Univeristy Press.

Dziobek, Claudia dan Pazarbazioglu, Ceyla. (1998). Lessons from Systematic Bank Restructuring: A Survey of 24 Countries. IMF: Economic Isuues No.14.

Frankel, Jeffrey A. (1998). Preventing Banking Crises dalam Preventing Bank Crises: Lessons from Recent Global Bank Failures diedit oleh Caprio, Gerrard Jr. dkk. Washington, D.C.: the World Bank.

Lane, Timothy dan Phillips, Steven. (2002). Moral Hazard, Does IMF Financing Encourage Imprudence by Borrowers and Lenders? IMF Economic Issues No.28

Min, Yoo Seong. (1999). Corporate Restructuring in Korea dalam Korea and the Asian Economic Crisis: One Year Later. Washington, D.C.: Georgetown University, the Korea Economic Institute of America, dan the Korea Institute for International Economic Policy.

Nellor, David C.L. (1998). The Role of International Monetary Fund dalam East Asian in Crisis, From Being a Miracle to Needing One? diedit oleh Ross H.McLeod dan Ross Garnaut. London: Routledge.

Slatter, Stuart dan Lovet, David. (1999). Corporate Turnaround. New York: Pinguin Books. 
Stone, Mark R. (2002). Corporate Sector Resyructuring, the Role of Government in Times of Crisis. IMF: Economic Issues No.31.

The World Bank. (2000). East Asia, Recovery and Beyond. Washington D.C.: the World Bank.

Wanandi, Sofyan. (1999). The Post-Soeharto Business Environment dalam PostSoeharto Indonesia, renewal or Chaos diedit oleh Geoff Forester. Singapura: Institute of Southeast Asian Studies. 